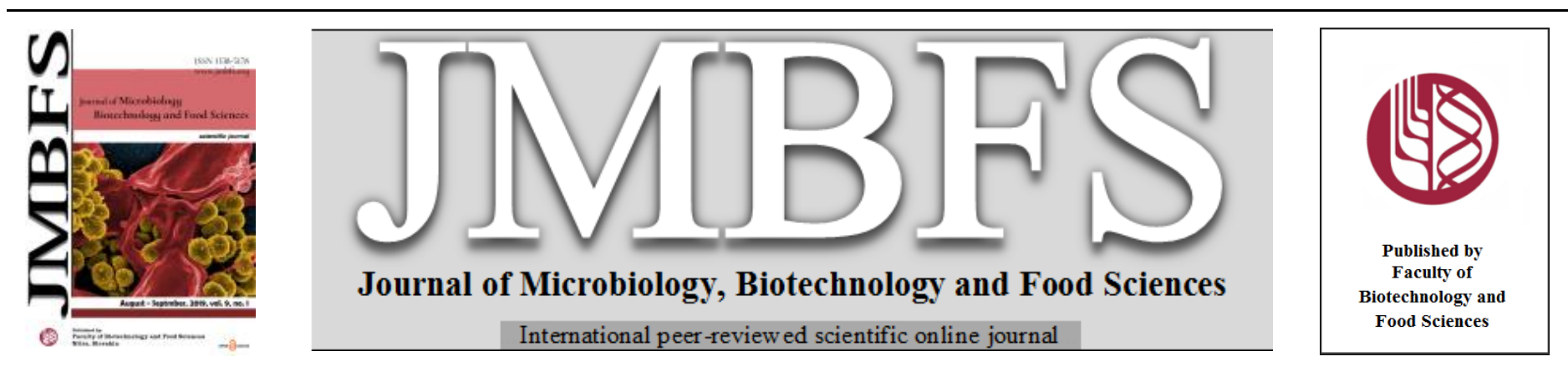

\title{
SOME INDICES' DETERMINATION OF RAW AND PASTEURIZED COW MILK BY UKRAINIAN MANUFACTURERS USING UNIQUE EXPRESS METHODS
}

\author{
Nadia M. Bogatko ${ }^{*}$, Natalia V. Bukalova ${ }^{I}$, Vasil P. Lyasota ${ }^{1}$, Lyudmyla P. Artemenko ${ }^{1}$, Leonid M. Bogatko ${ }^{1}$, Tetiana I. Bakhur ${ }^{1}$ \\ Tetiana M. Prilipko ${ }^{2}$, Inna V. Zabarna ${ }^{2}$,Lubov B. Savchuk ${ }^{2}$, Svetlana A. Tkachuk ${ }^{3}$
}

$\operatorname{Address(es):~}$

${ }^{1}$ Bila Tserkva National agrarian University, Bila Tserkva, Kyiv region, Ukraine.

${ }^{2}$ State Agrarian and Engineering University in Podilya, Kamianets-Podilskyi, Khmelnytskyi region, Ukraine.

${ }^{3}$ Institute of Veterinary Medicine of the National Academy of Sciences of Ukraine, Kyiv, Ukraine.

*Corresponding author: nadiyabogatko@ukr.net

doi: 10.15414/jmbfs.2019.9.1.9-14

\section{ARTICLE INFO}

Received 21.8. 2018

Revised 18. 2. 2019

Accepted 18. 2. 2019

Published 1. 8. 2019

Regular article open $O$ access

\begin{abstract}
According to the Regulation (EC) of the European Parliament and of the Council of the European Union No. 852/2004 and No. 853/2004 "On the hygiene of foodstuffs" dated April 29, 2004, Ukrainian producers of both pasteurized and raw cow's milk should be guided by regulatory acts, in particular, DSTU 2661:2010 "Drinkable cow's milk. General technical conditions" and DSTU 3662:2015 "Cow's milk-raw. Technical conditions", which are harmonized to the requirements of the EU, and are regulating the safety and quality of milk for adhering to the proper sanitary and hygienic requirements of their primary production and industrial processing, and use modern, effective developed and tested rapid control methods of milk and dairy products for their falsification.

Taking into account that today the falsification of milk as pasteurized and raw is not a rare occurrence, it is especially important to develop and introduce new express methods for the detection of various chemical reagents in dairy products that impair their quality and can affect their safety.

We have developed simple, effective, reliable express methods: the determination of the number of somatic cells in milk by using Reagent N; detection of milk falsification by sodium bicarbonate using an alcoholic solution of bromocresol green with a mass concentration of $0.01 \%$; as well as by alkaline detergents using an alcoholic solution of bromotymol blue with a mass concentration of $0.02 \%$.

Determination of the number of somatic cells in cow's milk by express method using Reagent $\mathrm{N}$ gave a $99.8 \%$ confidence in qualitative indices. The colour and consistency of milk varies, depending on the number of somatic cells - from liquid with bright orange to the formation of a jelly-like clay dark-raspberry colour which is easily removed from the hole of the dairy plate.

An express method for detecting falsification of milk by sodium bicarbonate has the following advantages over existing commonly used methods: the results are specific, with a reliable qualitative index of $99.9 \%$, consisting in changing the colour of the circular layer of milk, depending on the amount of baking soda added to it. In the absence of sodium hydro-carbonate, the colour of the circular layer of milk has a dark green colour, and if it is present, it acquires a dark blue-green colour of varying intensity.

The express method of the milk falsification determining by alkaline detergents is easy to implement, and its results give specific qualitative indicators of $99.9 \%$. Depending on the amount of alkaline detergents added to the container with milk (up to $1,5,10 \%$ ), the milk acquires a blue colour varying intensity.
\end{abstract}

Keywords: milk, safety, quality, express methods, approbation, somatic cells, falsification, Reagent N reagent, sodium bicarbonate, bromocresol green, alkaline detergents, bromotymol blue

\section{INTRODUCTION}

Provision of high-quality livestock products, in general, with milk and dairy products, in particular, is one of the most important tasks of the agrarian sector of Ukraine workers.

Milk refers to essential food products and it is one of the food security's ingredients in any country. According to the classification of experts from the UN FAO, milk is one of the most valuable human food products, without which it is impossible to cultivate a full-fledged young generation of people (Regulation (EC) of the European Parliament and of the Council on 29.04.2004 №852/2004).

Qualitative and safe milk, suitable for the production of high-quality dairy products and baby food products, can be produced only by dairy farms with the introduction of a system for ensuring the safety of its receipt, primary processing and storage (HACCP) and a modern milk-raw material control system (Bryan, 2013).

Ukraine is implementing the necessary reforms to adapt the legal regime of food safety and quality in full compliance with the WTO Agreement on the Application of Sanitary and Phyto-sanitary Measures, and simultaneously harmonizes national legislation with the requirements of the European Community (Regulation (EC) of the European Parliament and of the Council on 28.01.2002 №178/2002; The Law of Ukraine "On basis principles and requirements for safety and quality of food" №1602-VII, 22.07.2014; The Law of Ukraine “On Milk and Dairy Products" No. 30, 2004).

Ukrainian manufacturers are guided by legal acts that are regulating the safety and quality of milk, improve the standards of safety and quality of dairy products, and predict that milk, dairy raw and dairy products, are in line with their normalized indexes (DSTU 2661:2010; DSTU 3662:2015; The Rules of veterinary and sanitary examination of milk and dairy products and requirements for their implementation, Order No. 49, 20.04. 2004); The Law of Ukraine "On Amendments to the Law of Ukraine" On Milk and Dairy Products, 2010).

The primary issue is the safety of milk-raw materials, which in many cases does not meet the requirements of European standards, especially for bacterial insemination (Aminov, 2009), due to insufficiency and unsatisfactory quality of feed (Barkema et al, 2009), non-compliance with sanitary and hygienic requirements at the time of receipt (Fenlon, 2005), primary processing, storage and transportation of milk (Garg \& Mital, 2012), inadequate condition of milking and refrigeration equipment (Hulebak \& Schlosser, 2012), insufficient funds for cleaning and disinfection (Jayarao et al, 2006), the presence of dairy cows' mastitis (Kivaria et al, 2006). 
Therefore, the purpose of our work was to develop express methods for detecting falsification of milk by sodium bicarbonate and alkaline detergents to ensure proper sanitary and hygienic conditions for milk producers. There is no information in foreign publications on the development of express methods for the determination of milk falsification by sodium bicarbonate and alkaline detergents, since the control of milk production is carried out through the traceability system (ISO/DIS 22005:2005).

We also developed a method for determining the number of somatic cells in milk using a Reagent N solution. Foreign scientists argue (Eberhart et al, 1982), that farmers in the EU, USA, Canada widely use information capabilities of the number of somatic cells in milk of cows. In particular, in this way they determine the level of animals' morbidity for mastitis in the herd. It does not take much time, since the number of somatic cells is determined by an automatic electronic counter in a sample of milk. Such counters in developed countries are provided by all farmers. It should be noted that some Ukrainian farms also use electronic counters for somatic cell counting. However, our farmers use them one-sidedly only to establish a degree of milk. However, they do not take into account the possibility of using this indicator, such as receiving information about the mastitis situation in the herd.

Taking into account the above, there is a need not only to closely monitor the safety and quality of milk as raw materials and pasteurized, but also to preven the risk analysis in the production of whole milk from cows to determine the critical points of management of the process of its receipt (Magnusson et al, 2017).

\section{MATERIAL AND METHODS}

The research was carried out on the cow pasteurized milk of trademarks "Vita" (PAT-ZhLK "Ukraine") and "Yagotinske" (Yagotinsky Dairy Factory); as well as on raw cow's milk obtained from private peasant farms sold at the agrarian markets No 1 and No 3 of Bila Tserkva city (Kyiv region, Ukraine) in conditions of accredited laboratories of Veterinary and Sanitary Examination, Livestock Hygiene Products of the Department of Veterinary and Sanitary Examination, Hygiene of Livestock Products and Pathological Anatomy named after J. S Zagayevsky, and also of the Department of Veterinary and Sanitary Examination of the Institute of Postgraduate Training of Veterinary Medicine Managers and Specialists of the Bila Tserkva National Agrarian University.

Sampling in the amount of $0.5 \mathrm{dm}^{3}$ and preparation of these samples for evaluation analysis of investigated milk parameters, its' quality and safety were carried out in accordance with the requirements of DSTU 4834:2007. Indicators of milk quality and safety were determined according to the normative documents: density - using an areometr AM type (density and temperature scale), preheating a sample of milk in the amount of $250 \mathrm{~cm}^{3}$ to $35 \pm 5^{\circ} \mathrm{C}$, and gently mixing and cooling to $20 \pm 2{ }^{\circ} \mathrm{C}$; the degree of mechanical pollution - filtering milk samples in the amount of $250 \mathrm{~cm}^{3}$ and counting the number of mechanical impurities; acidity - by the titrimetric method, due to the neutralization of acids contained in milk, an excess amount of sodium hydroxide solution in the presence of an indicator - an alcoholic solution of phenolphthalein with a mass concentration of $1 \%$ until a pale pink appearance occurs; the mass fraction of dry matter and dry skim milk residue - by the calculation method according to the formulas, taking into account the parameters of density, fat content; mass fractions of fat and protein - with the help of the device "Ekomilk"; freezing point of milk - by cryoscopic method, using a cryoscope, and an increase in the freezing point of milk due to addition of water or other inhibitory substances; the degree of bacterial insemination (the number of mesophilic aerobic and optional anaerobic microorganisms, NMAOAM) - by setting up a reductase test with resazurin, which is recovered by the oxidative-reducing enzymes of the microorganisms present in the milk, and by the duration of discoloration of resazurin, assessing the bacterial contamination of the milk.

The presence of inhibitory substances is not allowed in milk, therefore, for the detection of sodium hydro-carbonate, hydrogen peroxide, starch, formalin, ammonia, chlorine, and water, we used qualitative reactions, in particular, our express methods have been developed.

For the first time, developed express methods:

1) Determining the number of somatic cells in milk using a solution of Reagent $\mathrm{N}$ (Austria), which has an alkaline reaction (Patent of Ukraine on the utility model №118247, 2017). Research progress: milk samples in the amount of 1.0 $1.1 \mathrm{~cm}^{3}$ are poured into a milk plate, graduated pipette add $1.0-1.1 \mathrm{~cm}^{3}$ of Reagent $\mathrm{N}$ solution, stirring with circular motions. After 1-2 seconds, the formation of a mixture is stated: from a bright orange colour of a liquid consistency to a dark-raspberry colour of varying intensity, with the formation of a large jelly-like clot that is removed from the lobes of the milk plate, which depends on the number of somatic cells in the milk samples under study (less than 100000 of somatic cells $/ \mathrm{cm}^{3} ; 100000-300000 / \mathrm{cm}^{3} ; 300000-500000 /$ $\mathrm{cm}^{3}$; 500 000-1 $500000 / \mathrm{cm}^{3}$; more than $\left.1500000 / \mathrm{cm}^{3}\right)$.

2) Detection of milk falsification by sodium hydro-carbonate, which has an alkaline reaction (for long-term storage, elimination of signs of deterioration and reduction of insemination by microorganisms), using an alcoholic solution of bromocresol green with a mass concentration of $0.01 \%$ (Patent of Ukraine on the utility model №118246, 2017). The method is based on the use of an alcoholic solution of bromocresol green with a mass concentration of $0,01 \%$ in the amount of $0,2-0,4 \mathrm{~cm}^{3}$ and the presence of dark green colour of the ring layer - in the absence of an impurity of sodium bicarbonate; or dark blue-green colour of different intensity of the ring layer - depending on the amount of added sodium bicarbonate in the capacity of milk (up to $0.01 \%$ - the ring layer of bluegreen colour, to $0.05-0.1 \%$ - dark green-blue , to $0.25-0.5 \%$ - dark blue)

3) Detection of milk falsification by alkaline detergents containing alkaline compounds (for long-term storage, elimination of signs of deterioration and reduction of insemination by microorganisms), using an alcoholic solution of bromotymol blue with a mass concentration of $0.02 \%$ (Patent of Ukraine on the utility model №116523, 2017). The method is based on the use of $0,2-0,4 \mathrm{~cm}^{3}$ of alcohol solution of bromotymol blue with a mass concentration of $0,02 \%$ to determine the absence or presence of a mixture of blue colour different intensity, depending on the amount of added detergents (up to $1 \%$ - a mixture of light blue , up to $5 \%$ - blue, up to $10 \%$ - bright blue).

\section{RESULTS}

The legal requirement for milk production (in dairy farms) is Regulation (EC) No 178/2002 of the European Parliament and of the Council, which covers the general principles and requirements of food law and defines procedures for the safety of foodstuffs (The Law of Ukraine "On basis principles and requirements for safety and quality of food” №1602-VII, 22.07.2014)

Thus, milk pasteurized must meet the requirements of DSTU 2661:2010 According to the organoleptic parameters, the milk we examined was a homogeneous liquid, without siege, flakes of protein and lumps of fat, taste and smell - pure, without foreign flavours and odours, not inherent to fresh milk, the colour was white, uniform in hole mass.

Table 1 provides data on the quality and safety of test samples of pasteurized milk from different producers in comparison with the norm of parameters of pasteurized milk according to DSTU 2661:2010.

$\underline{\text { Table } 1 \text { Indicators of quality and safety of pasteurized cow's milk from different manufacturers }(M \pm m, n=22)}$

\begin{tabular}{|c|c|c|c|}
\hline Indexes & $\begin{array}{l}\text { Standard for Extra Class } \\
\text { (DSTU 2661: 2010) }\end{array}$ & $\begin{array}{c}\text { Cow's milk pasteurized } \\
\text { TM "Vita", } \\
n=12 \\
\end{array}$ & $\begin{array}{c}\text { Cow's milk pasteurized } \\
\text { TM "Yagotynske" } \\
n=10\end{array}$ \\
\hline Acidity, ${ }^{\circ} \mathrm{T}$ & not more then 20.0 & $16.0 \pm 0.09$ & $17.0 \pm 0.07$ \\
\hline Group of purity & $\begin{array}{c}\text { not less then I group (amount } \\
\text { of mechanical impurities - } \\
\text { up to } 2 \text { pieces) }\end{array}$ & $\begin{array}{c}\text { II } \\
5.0 \pm 0.04\end{array}$ & $\begin{array}{c}\mathrm{I} \\
2.0 \pm 0.05\end{array}$ \\
\hline Number of mesophilic aerobic and & & \multicolumn{2}{|c|}{ by reductase test - lilac colour } \\
\hline $\begin{array}{l}\text { optional anaerobic microorganisms } \\
\text { (NMAOAM), } \\
\text { Colony Forming Units (CFU)/ } \mathrm{cm}^{3}\end{array}$ & not more then 1000 & $(6.25 \pm 0.24) \times 10^{2}$ & $(5.85 \pm 0.32) \times 10^{2}$ \\
\hline $\begin{array}{l}\text { Density, } \mathrm{kg} / \mathrm{m}^{3}, \text { for the milk with fat } \\
\text { content from } 2,50 \text { to } 4,55 \% \text {, not less }\end{array}$ & 1027.0 & $1025.4 \pm 0.21$ & $1026.6 \pm 1.71$ \\
\hline Mass fraction of fat, $\%$ & from 1.0 to 6.0 & $2.33 \pm 0.07$ & $3.18 \pm 0.04$ \\
\hline $\begin{array}{l}\text { Mass fraction of protein, } \% \text {, for the } \\
\text { milk with fat content from } 2,50 \text { to } \\
4,55 \% \text {, not less }\end{array}$ & 2.8 & $2.69 \pm 0.05$ & $2.86 \pm 0.07$ \\
\hline Presence of phosphatase & absent & \multicolumn{2}{|c|}{ absent } \\
\hline Presence of peroxidase & absent & \multicolumn{2}{|c|}{ absent } \\
\hline $\begin{array}{l}\text { The temperature of the finished } \\
\text { product, }{ }^{\circ} \mathrm{C}\end{array}$ & $4 \pm 2$ & $4 \pm 2$ & $4.5 \pm 2$ \\
\hline
\end{tabular}


Analyzing the data in Table 1, it can be noted that milk pasteurized brands "Vita" and "Yagotynske" complied with the requirements of DSTU 2661:2010 according to indicators such as acidity (from $16.0 \pm 0.09$ to $17.0 \pm 0.07^{\circ} \mathrm{T}$ ), number of mesophilic aerobic and optional anaerobic microorganisms (NMAOAM) $(6.25 \pm 0.24) \times 10^{2}$ and $(5.85 \pm 0.32) \times 10^{2}$ Colony Forming Units $(\mathrm{CFU}) / \mathrm{cm}^{3}$ respectively, mass fraction of fat (from $2.33 \pm 0.07$ to $3.18 \pm 0.04 \%$ ) and the temperature of the finished product during release from enterprise (from $4 \pm 2$ to $\left.4.5 \pm 2^{\circ} \mathrm{C}\right)$.

In the pasteurized milk of different manufacturers it was not revealed: bacteria of the Escherichia Coli group (in $0.1 \mathrm{~cm}^{3}$ of the product); pathogenic microorganisms (in $25 \mathrm{~cm}^{3}$ of the product), including Salmonella, Listeria monocytogenes, Staphylococcus aureus (in $1.0 \mathrm{~cm}^{3}$ of the product).

It was established that the cow's pasteurized milk of TM "Vita" had a second group of cleanliness (5.0 0.04 mechanical impurities), which is not allowed by the current national standard. In addition, density indicators milk by TM "Vita" and TM "Yagotynske" were slightly lower than normalized at 1,002 and 1,0004 times ( $\mathrm{p} \leq 0,005)$, respectively. In pasteurized cow's milk by TM "Vita", the mass fraction of protein is lower in 1.04 times $(p \leq 0.01)$, compared to the normative indicators of DSTU 2661:2010. Density and protein data may indirectly indicate, in particular, the impurities of water in milk.

We also analyzed raw cow's milk obtained from private farms, which was implemented in the agro-industrial markets. It was established that according to the organoleptic evaluation, the milk was consistent with the following indices: natural whole, pure, without foreign flavours and odours which are not characteristic for fresh milk; in appearance and consistency - homogeneous, without siege and clusters, white-yellow colour.

Table 2 shows the quality and safety indexes of the investigated raw milk samples, which were realized on the agro-industrial markets, in comparison with the norms of raw cow's milk indicators, in accordance with the requirements of DSTU 3662:2015.

Table 2 Indicators of quality and safety of cow's raw milk, which was implemented in the agro-industrial markets $(\mathrm{M} \pm \mathrm{m}, \mathrm{n}=26)$

\begin{tabular}{|c|c|c|c|}
\hline Indexes & $\begin{array}{l}\text { Standard for Extra Class } \\
\text { (DSTU 3662:2015) }\end{array}$ & $\begin{array}{l}\text { Raw cow's milk (agro-industrial } \\
\text { market No 1), } n=12\end{array}$ & $\begin{array}{c}\text { Raw cow's milk (agro- } \\
\text { industrial market No 3), } \\
n=14\end{array}$ \\
\hline Acidity, ${ }^{\circ} \mathrm{T}$ & $16.0-17.0$ & $16.5 \pm 0.04$ & $17.0 \pm 0.05$ \\
\hline Group of purity & $\begin{array}{l}\text { not less then I group (amount of } \\
\text { mechanical impurities - up to } \\
2 \text { pieces) }\end{array}$ & $\begin{array}{c}\mathrm{I} \\
(2.0 \pm 0.05)\end{array}$ & $\begin{array}{c}\mathrm{I} \\
(2.0 \pm 0.05)\end{array}$ \\
\hline Number of mesophilic aerobic & & \multicolumn{2}{|c|}{ by reductase test - lilac colour } \\
\hline $\begin{array}{c}\text { and optional anaerobic } \\
\text { microorganisms, (NMAOAM), } \\
\text { Colony Forming Units } \\
(\mathrm{CFU}) / \mathrm{cm}^{3}\end{array}$ & $\leq 100$ & $(2.34 \pm 1.74) \times 10^{4}$ & $(3.75 \pm 1.68) \times 10^{4}$ \\
\hline Temperature, ${ }^{\circ} \mathrm{C}$ & $\leq 6$ & $8 \pm 2$ & $8 \pm 2$ \\
\hline Mass fraction of dry matter, $\%$ & $\geq 12.2$ & $12.25 \pm 0.08$ & $12.18 \pm 0.05$ \\
\hline $\begin{array}{l}\text { Dry non-fat milk residue } \\
\text { (DNMR), \% }\end{array}$ & $8.15-9.0$ & $8.75 \pm 0.09$ & $8.94 \pm 0.05$ \\
\hline $\begin{array}{c}\text { Number of somatic cells, } \\
\text { thousands } / \mathrm{cm}^{3} *\end{array}$ & $\leq 400$ & $340.22 \pm 36.40$ & $380.34 \pm 31.52$ \\
\hline Density, $\mathrm{kg} / \mathrm{m}^{3}$, at $\mathrm{t}^{\circ} 20^{\circ} \mathrm{C}$ & not less than 1027.0 & $1027.6 \pm 0.62$ & $1030.7 \pm 0.78$ \\
\hline Mass fraction of protein, $\%$ & 3.0 & $3.02 \pm 0.03$ & $3.06 \pm 0.03$ \\
\hline Mass fraction of fat, $\%$ & 3.4 & $3.44 \pm 0.04$ & $3.53 \pm 0.07$ \\
\hline Freezing point of milk, ${ }^{\circ} \mathrm{C}^{* *}$ & -0.520 & $-0.521 \pm 0.04$ & $-0.520 \pm 0.02$ \\
\hline
\end{tabular}

Raw milk, which was sold on agro-industrial markets No. 1 and No. 3 , corresponded to the extra-quality indicators regulated by DSTU 3662:2015, which indicated that it was properly produced in the conditions of private farms. In raw cow's milk index NMAOAM was $(2.34 \pm 1.74) \times 10^{4}$ $(3,75 \pm 1,68) \times 10^{4} \mathrm{CFU} / \mathrm{cm}^{3}$, which corresponded to an Extra Class of milk. In tested milk of it was not revealed: bacteria of the Escherichia Coli group (in 0.1 $\mathrm{cm}^{3}$ of the product); pathogenic microorganisms (in $25 \mathrm{~cm}^{3}$ of the product), including Salmonella, Listeria monocytogenes, Staphylococcus aureus (in 1.0 $\mathrm{cm}^{3}$ of the product).

The number of somatic cells in milk that was sold in the agro-industrial markets $\left(340.22 \pm 36.40-380.34 \pm 31.52\right.$ thousands $\left./ \mathrm{cm}^{3}\right)$, corresponded to the regulated value of the Extra Class milk-raw material

The freezing point of milk, which is somewhat lower than that of water, due to the presence of various soluble substances in it, was within the normal range and was minus $0.521 \pm 0.04-0.520 \pm 0.02{ }^{\circ} \mathrm{C}$.

Studies have also been conducted to determine the number of somatic cells developed by us using the new express method using the Reagent $\mathrm{N}$ solution (Patent of Ukraine on the utility model №118247, 2017).

The method for determining the number of somatic cells in milk using a Reagent $\mathrm{N}$ solution works like this. The investigated sample of milk in the amount of 1.0 $1.1 \mathrm{~cm}^{3}$ was poured into a milk plate; using graduated pipette added $1.0-1.1 \mathrm{~cm}^{3}$ of Reagent $\mathrm{N}$ solution, by stirred circular motions and after 1-2 sec. observed the change in the consistency of the mixture and its' colour depending on the number of somatic cells in the investigated milk samples.

With somatic cells less than $100000 / \mathrm{cm}^{3}$ - the consistency of a mixture of liquid, bright orange colour; from 100000 to $300000 / \mathrm{cm}^{3}$ - the mixture slightly gains and acquires orange-raspberry colour; from 300000 to $500000 / \mathrm{cm}^{3}$ - formation of gelatinous clay pinkish-raspberry colour; from 500000 to $1.5 \mathrm{millions} / \mathrm{cm}^{3}-\mathrm{a}$ large jelly-like clay of bright-raspberry colour; more than 1.5 millions $/ \mathrm{cm}^{3}$ of somatic cells is a significant gelatinous clot of dark-raspberry colour that is easily removed from the lobes of the milk plate.
Studies were also conducted to detect the falsification of milk by sodium hydro-carbonate (baking soda), using an alcoholic solution of bromocresol green with a mass concentration of $0.01 \%$ (Patent of Ukraine on the utility model №118246, 2017).

To determine falsification of milk by sodium hydro-carbonate using the express method with bromocresol green, we took the test sample of milk in the amount of $3.0-3.5 \mathrm{~cm}^{3}$. By graded pipette, carefully, on the wall of the test tube, added 0.2 $0.4 \mathrm{~cm}^{3}$ of bromocresol green alcoholic solution with a mass concentration of $0.01 \%$, and after $0.5-1$ sec., the colour of the circular layer of the formed mixture was determined, depending on the amount of added sodium hydro-carbonate in a container with milk.

The dark green colour of the circular layer of the tested milk sample indicates that there is no admixture of sodium hydro-carbonate in it. The formation of a dark blue-green colour varying intensity of a milk circular layer indicates the presence of sodium hydro-carbonate. At its' presence in the amount of $0.01 \%$, the circular layer of milk acquires a blue-green colour, $0.05-0.1 \%$ - dark green-blue, $0,25-0,5 \%$ - dark blue

For detection of milk falsification by alkaline detergents, a new express method was developed using an alcoholic solution of bromotymol blue with a mass concentration of $0.02 \%$ (Patent of Ukraine on the utility model №116523, 2017).

According to this method, to the investigated sample of milk in the amount of $2-3 \mathrm{~cm}^{3}$ by graduated pipette was added $0.2-0.4 \mathrm{~cm}^{3}$ of bromotymol blue alcohol solution with a mass concentration of $0.02 \%$. After 3-4 sec., the absence (negative reaction) or the presence of a blue colour of different intensity (positive reaction) depending on the amount of added detergents: up to $1 \%$ - the colour is light blue, up to $5 \%$ - blue, up to $10 \%$ - dark blue. The light yellow colour of milk indicates that there is no admixture of alkaline detergents.

The results of these studies are presented in Table 3 . 
Table 3 Determination of somatic cells number in milk and detecting of its' falsification ( $M \pm m, n=48)$

\begin{tabular}{|c|c|c|c|c|}
\hline \multirow[b]{2}{*}{ List of researches } & \multicolumn{4}{|c|}{ Indicators of pasteurized and raw milk from different manufacturers } \\
\hline & $\begin{array}{c}\text { Cow's milk } \\
\text { pasteurized, } \\
\text { TM "Vita", } \\
n=12 \\
\end{array}$ & $\begin{array}{c}\text { Cow's milk pasteurized, } \\
\text { TM "Yagotynske", } \\
n=10\end{array}$ & $\begin{array}{c}\text { Cow's milk raw (agro- } \\
\text { industrial market No } \\
1), n=12\end{array}$ & $\begin{array}{c}\text { Cow's milk raw (agro- } \\
\text { industrial market No } \\
3), n=14 \\
\end{array}$ \\
\hline \multicolumn{5}{|c|}{ Determination of somatic cells' number using reagents: } \\
\hline Mastidine & $\begin{array}{l}\text { Negative } \\
\text { reaction }\end{array}$ & $\begin{array}{c}\text { Negative } \\
\text { reaction }\end{array}$ & $\begin{array}{c}\text { Doubtful reaction } \\
\text { (tracks of jelly) }\end{array}$ & $\begin{array}{l}\text { Negative } \\
\text { reaction }\end{array}$ \\
\hline Mastoprim & \multicolumn{4}{|c|}{ from 100000 to 500000 somatic cells $/ \mathrm{cm}^{3}$} \\
\hline Reagent $\mathrm{N}$ & \multicolumn{4}{|c|}{ Less than $100000 / \mathrm{cm}^{3}$} \\
\hline \multicolumn{5}{|c|}{ Detection of milk falsification by, \%: } \\
\hline water & $10.70 \pm 0.03$ & $5.39 \pm 0.07$ & not found & not found \\
\hline sodium hydro-carbonate & \multicolumn{4}{|c|}{ not found } \\
\hline starch & \multicolumn{4}{|c|}{ not found } \\
\hline chlorine & \multicolumn{4}{|c|}{ not found } \\
\hline peroxide hydrogen & \multicolumn{4}{|c|}{ not found } \\
\hline formalin & \multicolumn{4}{|c|}{ not found } \\
\hline alkaline detergents, $\%$ & to 5 & to 1 & to 5 & not found \\
\hline
\end{tabular}

Thus, according to the results of determination of the number of somatic cells using the reagent Mastoprim, it was found that in the investigated milk samples, their number ranged from 100000 to $500000 / \mathrm{cm}^{3}$, and with Reagent $\mathrm{N}-$ less than $100000 / \mathrm{cm}^{3}$

As a result of milk research, using qualitative reactions to the presence of impurities of the investigated inhibitory substances, the absence of sodium hydrocarbonate, chlorine, peroxide of hydrogen, formalin and chlorine was established. However, falsification of milk was found by alkaline detergents and water.

\section{DISCUSSION}

Controlling the production of cow's raw and pasteurized milk of various brands is a scientifically sound system that guarantees the quality and safety of these products at the state level (Souto et al, 2008). Today, due to the difficult economic situation in Ukraine, price policy contributes to the fact that a significant part of the population prefers milk that is sold in the agro-food markets (Yatsenco $\boldsymbol{e t} \boldsymbol{a l}, \mathbf{2 0 1 6}$ ). Therefore it is necessary that raw milk producers comply with the veterinary and sanitary and hygienic requirements for its production (Winn, 2016; Vairamuthu et al, 2017).

As a result of the testing of pasteurized milk from the trademarks "Vita" and "Yagotynske", as well as raw milk from private farms, which came to the agroindustrial markets, it was found that the acidity index in the first case had a value of $16.0 \pm 0.09$ and $17.0 \pm 0.07^{\circ} \mathrm{T}$, respectively; $16.5 \pm 0.04$ and $17.0 \pm 0.05^{\circ} \mathrm{T}$ respectively - in the second one. These indicators corresponded to the regulated norms of the national standards of Ukraine DSTU 2661:2010 and DSTU 3662:2015. This fact is extremely important, because, according to Mola et al. (2014), the acidity of milk affects both the technological peculiarities of its primary production and contamination with pathogenic microflora. Therefore, according to these authors, for example, in ultra-pasteurized or tinned milk titrated acidity is allowed at a level not exceeding $21^{\circ} \mathrm{T}$.

It has been established that in pasteurized milk, both brands and raw milk obtained in private farms, which was implemented in the agro-industrial markets, were not revealed: bacteria of the Escherichia Coli group (in $0.1 \mathrm{~cm}^{3}$ of the product); pathogenic microorganisms (in $25 \mathrm{~cm}^{3}$ of the product), including Salmonella, Listeria monocytogenes, Staphylococcus aureus (in $1.0 \mathrm{~cm}^{3}$ of the product), and the indicator of NMAOAM did not exceed the permissible standards: $\quad(6.25 \pm 0.24) \times 10^{2}$ and $(5.85 \pm 0.32) \times 10^{2} \quad \mathrm{CFU} / \mathrm{cm}^{3}$ as like as $(2.30 \pm 1.74) \times 10^{4}$ and $(3.75 \pm 1.68) \times 10^{4} \mathrm{CFU} / \mathrm{cm}^{3}$ respectively. This means that the microbiological standard of collected fresh milk had a microbial number (NMAOAM) at the level of $40000 / \mathrm{cm}^{3}$, and raw milk with such a number of microorganisms, after its' next cooling to a temperature of $4^{\circ} \mathrm{C}$, can be transferred for processing after 24 hours as an extra class and have a microbial number less than $100000 / \mathrm{cm}^{3}$. Under these conditions, cooling the milk to a temperature of $8{ }^{\circ} \mathrm{C}$ allows to keep it within an exceptional grade for only 6 hours. That's why cooling milk is just a kind of preservation for a period of low temperature. This circumstance should become the main requirement of manufacturers for the construction of coolers of a new type, which would ensure the rapid cooling of milk to a temperature of $2 \ldots 4^{\circ} \mathrm{C}$ during 2 hours (Winn, 2016).

The absence of enzymes of phosphatase and peroxidase in pasteurized milk of both brands indicates the proper temperature regime both during the milk pasteurization process and its cooling.

The purity group also affects the degree of microbial contamination of milk. According to the results of our experiment, cow's pasteurized milk from TM "Vita" corresponded to the II group of cleanliness $(5.0 \pm 0.04$ mechanical impurities). According to Muir (2006) there should be no mechanical impurities in pasteurized milk, as this parameter affects its safety, in particular, bacterial insemination. The increase of the total NMAOAM, according to Moraes et al. (2012), affects not only the safety of milk, but also worsens its qualitative indicators such as reducing the amount of vitamins, the mass fraction of fat, protein, dry matter, etc.

Pasteurized milk from the trademarks "Vita" and "Yagotynske", at the time of release from the factory, complied with the requirements of DSTU 2661:2010 for such indicators as the mass fraction of fat $-2.33 \pm 0.07 \%$ and $3.18 \pm 0.04 \%$ (in the norm from 1.0 to $6.0 \%$ ) and the temperature $-4-4.5 \pm 2{ }^{\circ} \mathrm{C}$ (in the norm $4 \pm 2{ }^{\circ} \mathrm{C}$ ), respectively. The last indicator is important in terms of preventing the reproduction of residual microorganisms in pasteurized milk.

In cow's pasteurized milk of TM "Vita" the mass fraction of the protein was lower in 1.04 times $(\mathrm{p} \leq 0.01)-2.69 \pm 0.05 \%$ and $2.86 \pm 0.07 \%$ respectively (the norm is $2.8 \%$ according to DSTU $2661: 2010$ ).

The results of our research are convincing about the possibility of falsification of milk by water, since in milk from TM "Vita" and "Yagotynske", the amount of water was $10.70 \pm 0.03 \%$ and $5.39 \pm 0.07 \%$ respectively, which led to a decrease in the density of milk. The density of pasteurized milk from both brands was $1025.4 \pm 0.21$ and $1026.6 \pm 1.71 \mathrm{~kg} / \mathrm{m}^{3}$, respectively. Thus, the rates were somewhat lower than normalized in 1.002 and 1.0004 times $(p \leq 0,005)$ respectively, which indirectly indicates the presence of water.

This is significant, since the density index and fat content are used to calculate the amount of dry matter and the dry nonfat milk residue to convert the milk content from volumetric to weight units, as well as to determine its naturalness. In this context, it is important to know the causes of the increased amount of water in the finished product, since this may not always be the result of its simple addition into the milk. Often the reason lies in the mismatch of the diet, inadequate or excessive content of mineral and other nutrients in it, and also the imbalance of the energy-protein ratio. In addition, dilution of milk with water can occur due to technical malfunction in the system of washing milking or refrigeration equipment.

In the investigated raw cow's milk from personal peasant farms, which was implemented in the agro-industrial markets, water impurities were not detected.

Raw milk that was sold on agro-markets No.1 and No.3 corresponded to the regulated indicators of the extra class in accordance with DSTU 3662:2015. That was a sign that the primary production of raw milk in the conditions of private households is appropriate. As it was point out by Oliver and Murinda (2011), the consumption of such high-quality and safe raw milk contributes to the improvement of human health and the strengthening of their immunity.

An important indicator of milk safety and its' suitability for processing is the somatic cells number, which depends on such factors as the age of the cow, the breed, the physiological state of the animal (periods of lactation, mammary gland disease).

Applying a solution of Reagent $\mathrm{N}$, it was found that somatic cells number in the investigated milk by different manufacturers was less than $100000 / \mathrm{cm}^{3}$. The reliability of the research results of the developed express method was $99.8 \%$. According to some researchers (Zeng et al, 2007), the indicator of the well-being of farms in subclinical mastitis of animals problem is the somatic cells number in milk from healthy cows, which is regulated by European legislation: from 150 thousand $/ \mathrm{cm}^{3}$ (Norway, Great Britain) to $400000 / \mathrm{cm}^{3}$ (EU countries). In Ukraine, this index is at the level of $400000 / \mathrm{cm}^{3}$ for extra class milk. We can assume that the number of somatic cells less than $100000 / \mathrm{cm}^{3}$ is not the norm mostly it is an indicator of falsification of raw milk by water.

It should be noted that, as scientists say (Ma et al, 2000; Chassagne et al, 2005), dairy producers in the EU, USA, Canada, etc. prefer raw milk with low levels of somatic cells, and therefore offer financial incentives for farmers to produce high-quality milk with optimal levels of such cells. Milk with high content of somatic cells is undesirable for dairy processing enterprises, because it is less stable for storage, it lower the content of protein and elevated - of microorganisms. Even a slight increase in the number of somatic cells in a separate cow $\left(>100000 / \mathrm{cm}^{3}\right)$ lowers the protein content of milk. In addition, in milk with high content of somatic cells there are microorganisms - mastitis pathogens. 
Today, the falsification of milk both pasteurized and raw, is not a rare phenomenon. According to this fact, it is especially important to develop new express methods for detecting various chemical reagents that impair the quality of milk and can affect its safety. According to West (2015), one of the deterioration indicators of the milk quality is that it can contain impurities of detergents and disinfectants, as well as water.

According to the results of our studies, the fact of falsification of both pasteurized and raw milk, with some inhibitory substances, was prohibited by the current legislation of Ukraine.

The results of falsification of pasteurized milk from the trademarks "Vita" and "Yagotynske" and raw milk sold in the agro-industrial markets, obtained through qualitative reactions to the detection of the presence of impurities of such inhibitory substances as sodium hydro-carbonate, chlorine, peroxide of hydrogen, formalin and chlorine.

However, the use of the express-method developed by us (using an alcoholic solution of bromotymol blue with a mass concentration of $0.02 \%$ ) made it possible to detect the presence of alkaline detergents in pasteurized milk "Vita" and "Yagotynske" brands, up to $5 \%$ and $1 \%$ respectively, also in raw milk that was sold on the agro-industrial market No. 1 - up to $5 \%$. This method has $99.9 \%$ reliability of the research results.

We also tested an express method for determining falsification of milk by sodium hydro-carbonate (using an alcohol solution of bromocresol green with a mass concentration of $0.01 \%$ ). The presence of sodium hydro-carbonate admixture in the investigated pasteurized and raw milk was not established. This method has $99.9 \%$ reliability of the research results.

The results of the analysis of the investigated cow's milk provided by us give grounds to speak about the need for more strict control over the observance of sanitary and hygiene requirements during the initial production of milk, which will allow the use of appropriate corrective actions to obtain high-quality and safe milk products.

\section{CONCLUSIONS}

Ukrainian manufacturers of pasteurized and raw cow's milk should be guided by regulatory acts, in particular, DSTU 2661:2020 and DSTU 3662:2015, which are regulating milk safety and quality for the proper sanitary and hygienic requirements of their production, as well as use developed and tested rapid milk control methods to determine its falsification.

1. Milk of trademarks "Vita" and "Yagotynske" complied with the norms of DSTU 2661:2010 according to indicators such as organoleptic, acidity, the number of mesophilic aerobic and optional anaerobic microorganisms, mass fraction of fat and temperature during release from the enterprise.

2. Milk of cow pasteurized TM "Vita" has a second group of cleanliness (5.0 \pm 0.04 mechanical impurities). The indicators of milk density of TM "Vita" and TM "Yagotynske" were slightly lower than normalized in 1.002 and 1.0004 times $(\mathrm{p} \leq 0.005)$, respectively. The mass fraction of protein in pasteurized milk of TM "Vita" was lower in 1.04 times $(\mathrm{p} \leq 0.01)$, compared with the regulated indicators of DSTU 2661:2010. This indirectly indicates the presence of water impurities.

3. Milk, which was sold in the agro-industrial markets, according to organoleptic parameters, density, acidity, mass fraction of protein, dry fat-free residue, dry matter, the number of mesophilic aerobic and optional anaerobic microorganisms conforms to the extra-quality indicators in accordance with the requirements of the national standard of Ukraine (DSTU 3662:2015)

4. The falsification of milk by the trademarks "Vita" and "Yagotynske" was established, as well as the milk that was sold in the agroindustrial market No. 1 , with alkaline detergents (up to $5 \%$, up to $1 \%$ and up to $5 \%$ respectively). Also, an admixture of water in milk of the brands "Vita" and "Yagotynske" was found $(10.70 \pm 0.03$ and $5.39 \pm 0.07 \%$ respectively).

5. Express methods we developed to determine the number of somatic cells in the milk of cows (using Reagent $\mathrm{N}$ ), falsification of milk by sodium bicarbonate (using an alcoholic solution of bromocresol green with a mass concentration of $0.01 \%$ ) and alkaline detergents (using alcoholic solution bromotymol blue with a mass concentration of $0.02 \%$ ) were reliable at $99.8-99.9 \%$.

The prospect of further research is to investigate the biological and chemical risks of milk falsification under different conditions of primary production and industrial processing, and to develop a risk-oriented milk safety monitoring system for Ukrainian producers.

\section{REFERENCES}

Aminov, R. I. (2009). The role of antibiotics and antibiotic resistance in nature cow's milk. Environmental Microbiology, 11(12), 2970-2988. https://doi.org/10.1111/j.1462-2920.2009.01972.x

Barkema, H. W., Van der Ploeg, J. D., Schukken, Y. H., Lam, T. J. G. M., Benedictus, G., \& Brand A. (2009). Management style and its association with bulk milk somatic cell count and incidence rate of clinical mastitis. J Dairy Sci, 82(8), 1655-1663. https://doi.org/10.3168/jds.S0022-0302(99)75394-4

Bogatko, N. M., Bukalova, N. V., Prylipko, T. M., Bogatko, L. M., \& Neborachok, M. V. (2017). Method of determining milk falsification by alkaline detergents: Patent of Ukraine on the utility model No 116523. G01N 33/04 (2006.01). 3 p.

Bogatko, N. M., Mazur, T. H., Shchurevych, H. P., \& Bogatko, L. M. (2017) Method for determining of somatic cells number in milk using a solution of Reagent N: Patent of Ukraine on the utility model No 118247. MPK G01N 33/04 (2006.01). 4 p.

Bogatko, N. M., Mazur, T. H., Shchurevych, H. P., \& Bogatko, L. M. (2017) Method of determining falsification of milk by sodium hydro-carbonate using bromocresol green: Patent of Ukraine on the utility model No 118246. G01N 33/04 (2006.01). 4 p.

Bryan, F. L. (2013). Epidemiology of milk-borne diseases. Journal of Food Protection, 46(7), 637-649. https://doi.org/10.4315/0362-028X-46.7.637

Chassagne, M., Barnouin, J. \& Le Guenic, M. (2005). Expert assessment study of milking and hygiene practices characterizing very low somatic cell score herds in France. J. Dairy Sci., 88(5), 1909-1916. https://doi.org/10.3168/jds.S0022 $\underline{0302(05) 72867-8}$

Cow's milk - raw material. Specifications: DSTU 3662:2015. Derzhspozhyvstandart of Ukraine (2017). 8 p. (National Standard of Ukraine). Drinkable cow's milk. General technical conditions: DSTU 2661:2010 Derzhspozhyvstandart of Ukraine (2011). 17 p. (National Standard of Ukraine).

Eberhart, R. J., Hutchinson, L. J., \& Spencer S. B. (1982). Relationships of Bulk Tank Somatic Cell Counts to Prevalence of Intramammary Infection and to Indices of Herd Production. Journal of Food Protection, Vol. 45, No. 12, 11251128. https://doi.org/10.4315/0362-028X-45.12.1125

Fenlon, D. R. (2005). A study of mastitis bacteria and herdmanagement practices to identify their relationship to high somatic cell counts in bulk tank milk. British Veterinary Journal, $151 \quad$ (1), 17-25. https://doi.org/10.1016/S00071935(05)80059-4

Garg, S. K., \& Mital, B. K. (2012). Enterococci in Milk and Milk-Products Critical Reviews in Microbiology, 18(1), 15-45 https://doi.org/10.3109/10408419109113508

Hulebak, K. L., \& Schlosser W. (2012). Hazard analysis and critical control point (HACCP) history and conceptual overview. Risk analysis, 22(3), 547-552. https://doi.org/10.1111/0272-4332.00038

ISO/DIS 22005:2005. Tractability in the feed and food chain - General principles and basis requirements for system design and implementation: Draft international standard. - ISO, 2005. - $13 \mathrm{p}$

Jayarao, B. M., Donaldson, S. C., Straley, B. A., Sawant, A. A., Hegde, N. V., \& Brown, J. L. (2006). A survey of food borne pathogens in bulk tank milk and raw milk consumption among farm families in Pennsylvania. Journal of dairy science, 89(7), 2451-2458. https://doi.org/10.3168/jds.S0022-0302(06)72318-9 Kivaria, F. M., Noordhuizen, J., \& Kapaga, A. M. (2006). Evaluation of the hygienic quality and associated public health hazards of raw milk marketed by smallholder dairy producers in the Dar es Salaam region, Tanzania. Tropical Animal Health and Production, 38(3), 185-194. https://doi.org/10.1007/s11250 006-4339-y

Ma, Y., Ryan, C., Barbano, D. M., Galton, D. M., Rudan, M. A. \& Boor, K. J (2000). Effects of somatic cell count on quality and shelf-life of pasteurized fluid milk. Journal of dairy science, 83(2), 264-274 https://doi.org/10.3168/jds.S0022-0302(00)74873-9

Magnusson, M., Christiansson, A., \& Svensson, B. (2017). Bacillus cereus spores during housing of dairy cows: factors affecting contamination of raw milk. Journal of dairy science, 90(6), 2745-2754. https://doi.org/10.3168/jds.2006-754 Mola, Y., Dabassa, A., \& Demissie, S. (2014). Evaluation of Methicillin Resistance among Staphylococcus aureus Isolated from some Cream Field Bakery Products in Jimma Town. Research Journal of Microbiology, 9(1), 1624. https://doi.org/10.3923/jm.2013

Moraes, P. M., Perin, L. M., Todorov, S. D., Silva Jr, A., Franco, B. D. G. M., \& Nero, L. A. (2012). Bacteriocinogenic and virulence potential of Enterococcusisolates obtained from raw milk and cheese. Journal of Applied Microbiology, 113(2), 318-328. $\quad$ https://doi.org/10.1111/j.13652672.2012.05341.x

Muir, D. D. (2006). The shelf-life of dairy products: 1. Factors influencing raw milk and fresh products. International Journal of Dairy Technology, 49(1), 24 32. https://doi.org/10.1111/j.1471-0307.1996.tb02616.x

Okpalugo, J., Ibrahim, K., Izebe, K. S., \& Inyang, U. S. (2008). Aspects of microbial quality of some milk products in Abuja, Nigeria. Tropical Journal of $\begin{array}{lll}\text { Pharmaceutical } & \text { Research, } & \text { 1169-1177. }\end{array}$ http://dx.doi.org/10.4314/tipr.v7i4.14703

Oliver, S. P. \& Murinda, S. E. (2011). Milk and raw milk consumption as a vector for human disease. $\mathrm{CAB}$ International. Zoonotic Pathogens in the Food Chain.

Regulation (EC) of the European Parliament and of the Council on 29.04.2004 №852/2004 "On the hygiene of foodstuffs". https://eur-lex.europa.eu/legalcontent/EN/TXT/?uri=CELEX\%3A32004R0852

Regulation (EC) of the European Parliament and of the Council on 28.01.2002 №178/2002, laying down the general principles and requirements of food law, establishing the European Food Safety Authority and laying down procedures in matters of food safety. http://www.reachteam.eu/chinese/REACH ME/engine/sources/regulations/launch-178-2002-EC.html 
Souto, L. I., Minagawa, C. Y., Telles, E. O., \& Garbuglio, M. A. (2008) Relationship between occurrence of mastitis pathogens in dairy cattle herds and raw-milk indicators of hygienic-sanitary quality. J Dairy Res, 75, 121-127. https://doi.org/10.1017/S0022029907002907

The Law of Ukraine "On Amendments to the Law of Ukraine" On Milk and Dairy Products. Shuttle The Verkhovna Rada of Ukraine 10.05., 15.04.2010, No 2132-VI.

The Law of Ukraine "On basis principles and requirements for safety and quality of food". Approved. Verhovna Rada of Ukraine No 1602-VII from 22.07.2014.

The Law of Ukraine "On Milk and Dairy Products" (2004). The Official Bulletin of Ukraine, No. 30. 47 p.

The Rules of veterinary and sanitary examination of milk and dairy products and requirements for their implementation. Shuttle State Department of Veter. Medicine, Order No. 49 of 20.04. 2004, Registered in the Ministry of Justice of Ukraine 07.05. 2004, No 579/9178.

Vairamuthu, S., Sinniah, J., \& Nagalingam, K. (2017). Factors influencing production of hygienic raw milk by small scale dairy producers in selected areas of the Jaffna district, Sri Lanka. Tropical Animal Health and Production, 42(3), 357-362. https://doi.org/10.1007/s11250-009-9427-3

West, H. G. (2015). Food fears and raw-milk cheese. Appetite, 51(1), 25-29. https://doi.org/10.1016/j.appet.2008.02.004

Winn, W. C. (2016). Koneman's color atlas and textbook of diagnostic microbiology, 6th ed. Lippincott Williams \& Wilkins.

Yatsenco, I. V., Bogatko, N. M., Bukalova, N. V., Fotina, T. I., Biben, I. A., Birgelevych, O. M., Binkevych, V. Ya., Gachak, Yu. R., Tkachuk, S. A., Kam'yans'kyy, V. V., Bondarevs'kyy, M. M., Zazhars'ka, N. M., Holovko, N. P., \& Kasyanenko, O. I. (2016). Hygiene of milk and dairy products. Part 1. Hygiene of milk: textbook. Kharkiv, Publishing House "Disa Plus".

Zeng, S. S., Chen, S. S., Bah, B., \& Tesfai K. (2007). Effect of extended storage on microbiological quality, somatic cell count, and composition of raw goat milk on a farm. Journal of Food Protection, 70(5), 1281-1285. https://doi.org/10.4315/0362-028X-70.5.1281 